\title{
Section: REVIEWS
}

\section{THE UKRAINIAN BANDURA AS A MUSICAL INSTRUMENT OF THE CHORDOPHONE GROUP}

\author{
VIOLETTA DUTCHAK
}

\begin{abstract}
The article examines the characteristics of the bandura as a plucked chordophone. A comparative analysis of the researches undertaken by outstanding musicologists, performers, ethno-organologists S. Lyudkevych, E. Hornbostel, C. Sachs, H. Khotkevych, Z. Shtokalko, and others is carried out. The morphology of the instrument and the main stages in its evolution are discussed. The stable and mobile elements of the bandura's structure and tuning are described. The technical characteristics of the instrument in different periods of its evolution and the achievements of the bandura makers and bandurists of Ukraine and the Ukrainian diaspora are analyzed. The common and distinguishing features of the bandura and some kindred instruments are pointed out.
\end{abstract}

Keywords: bandura, chordophone, plucked stringed instruments, instrument's morphology, construction.

The regional, typological, timbral, functional diversity of Ukrainian folk musical instruments is clear evidence of the artistic achievements of Ukraine. Throughout the history of the Ukrainian nation, the musical instruments were the proof of the autochthony and uniqueness of its musical style. The musical art of Ukraine was affected by general tendencies and common trends in the development of musical instrumentalism in Europe and Asia, yet the Ukrainian nation could be proud of its own instruments of original design, structure, and tuning that corresponded to its musical language; Ukrainian folk instruments were used for specific purposes in everyday life and rituals. S. Lyudkevych stated that 'every type of art, including music, from its very beginning and throughout its artistic development, has to be national, i.e. it has to rely on and correspond to the features of a national culture from which it emerges, a national culture which has developed in particular geographical, historical, or any other contexts'* $[6$, p. 35].

According to modern researchers, music makes it possible to present a nation through its culture, which 'innovates, improves, and enriches musical traditions giving them more efficient means of expression: the laws of composition, musical notation, instruments, techniques of singing and sound production' [12]. A musical instrument is a true representation of its epoch and environment. Its timbre, form and tuning, techniques and genres of performance, sphere of use, other specific features reflect its time, customs, culture, ethnic aesthetics, the level of social and technical progress.

\footnotetext{
${ }^{*}$ All quotations are translated from the original Ukrainian texts.
} 
Tracing an instrument's origin involves the analysis of two basic notions: its ethnic belonging and functions. M. Imkhanytskyi defines a folk instrument as 'a musical device used by several generations; it is an instrument other than a performer's vocal cords; with its help a performer makes music that is traditionally played in a particular national environment' [3, p. 19]. In the narrow sense of the word, folk musical instruments are used for only playing folk music; in the broad one, for performing both folk and professional music [11, p. 12]. The criteria of the folkness of an instrument is its traditionality, popularity with the people of a given ethnic or social group (community, society), who use it in order to express their national musical ideal.

The researchers distinguish between the notions of folk (characteristic of the prevailing part of society) and elite (typical of an 'exclusive' society or social stratum). A folk instrument, by definition, enables a performer to express thoughts and emotions through their own creative performance. The simultaneous existence of the same musical instrument as a folk one and an elite one within the same musical tradition presupposes that there are many and various transitional links between the two variants [3, p. 23]. The $20^{\text {th }}$ century created a broad palette of simultaneous, parallel existence of traditional and advanced Ukrainian folk instruments.

The epoch of Ukrainian folk instruments (including the bandura) and their study began somewhat later than those of academic instruments. The Ukrainian kobza-bandura attracted attention of ethnoorganologists only in the late $19^{\text {th }}$ century, and the researches continued into and throughout the 20th century. Musicologists, folklorists, ethnographers, bandura makers (P. Kulish, P. Zhytetsky, O. Famintsyn, M. Lysenko, L. Zhemchuzhnykov, O. Slastion, O. Rusov, P. Martynovych, S. Lyudkevych, H. Khotkevych, F. Kolessa, K. Kvitka, V. Yemetz) studied the form and tuning of the instrument, the character of sound production, regional varieties, the functional purpose of the instrument in everyday life and its role in rituals; they analyzed folklore samples, historical manuscripts, and artefacts. M. Lysenko, H. Khotkevych researched into the etymology of the names of musical instruments; K. Vertkov, L. Cherkaskyi, R. Levitsky, A. Horniatkevych, M. Khai, V. Kushpet, I. Zinkiv studied the impact of the general tendencies in the development of some kindred stringed instruments on the bandura; Z. Shtokalko, S. Lastovych-Chulivskyi, V. Mishalov, K. Cheremskyi, and others analyzed the positive and negative effects of its constructional modifications.

Still, certain issues retain their topicality: the analysis of the morphology of the bandura (a folk plucked chordophone); the analysis of the instrument's defining features, which, on the one hand, facilitate its integration into the world musical context and, on the other, help to preserve its originality. Such structural-typological analysis will make it possible to establish the place of the instrument in the general classification of plucked stringed musical instruments. The bandura has undergone many modifications; thus, another task is to look at stable and mobile aspects of its structure and tuning.

The principles of organology were laid down in the ancient world and further developed in the Middle Ages and during the Renaissance period. For chordophones (stringed instruments), the main ones are the timbre of an instrument, the method of sound production, the scale (tuning and temperament), the character of sound produced by plucked strings (depending on the length and thickness of the strings, the degree of string tension), the duration of sound. It is also important to establish the correlation between the ethnic and social aspects of a musical instrument. At different stages of the evolution of a musical instrument, these aspects reveal themselves in both its repertoire and popularity among various social segments.

In the late $19^{\text {th }}$-early $20^{\text {th }}$ century, folk instruments were included in the existing classification systems - a certain logical scheme was used in order to typologize them. In modern organology and ethno-organology, groups and classes of musical instruments of various historical periods are systematized according to the criteria of their structure and functions in the life of a particular ethnic group or nation.

Victor-Charles Mahillon (1880) [11] was the first to include folk instruments in a scientific catalogue. In his catalogue, all musical instruments were divided into four groups according to the criterion of the source of sound (direct feature): the air column, the string, the membrane, the body of an instrument. According to the method of sound production (indirect feature), musical instruments 
were divided into percussion instruments, friction musical instruments, bowed instruments, and embouchure musical instruments. The system was used by Hnat Khotkevych, who in 1930 published his extensive work Muzychni instrumenty ukrainskoho narodu (The Musical Instruments of the Ukrainian People) [10], a thorough analysis of the history of Ukrainian folk instruments. The author divided musical instruments into three groups: stringed, wind, and percussion instruments, each group having its own subgroups. For example, stringed instruments comprise the subgroups of bowed, plucked (harp-like), percussion instruments. Plucked stringed musical instruments were further subdivided into those with the neck and those without it. H. Khotkevych classified the kobza, the bandura, and the torban as lute-type instruments with the neck, against which the strings could be pressed down.

Using Mahillon's classification scheme, German organologists Erich Moritz von Hornbostel and Curt Sachs devised a complex system of musical instrument classification, a universal, international language of organology [15]. As some folk instruments had synonymous names, appropriate indexes helped to find necessary information concerning their characteristics, construction, the method of sound production, etc.

According to the Hornbostel-Sachs system, the main criteria of the classification of musical instruments are the source of sound, the method of sound production, and the construction. The classification system involves specifications: the form (symmetric and asymmetric forms like those of the zither and the lute), the construction (one-sided and two-sided instruments), tuning (non-equal tempered or modal tuning), the method of playing (sound production and playing techniques), the repertoire (melodic specificity, which depends on the construction and the method of playing the instrument), the organological factors (timbre, acoustics) and the organological and phonic factors (the technique of sound production, the picking style).

Within the group of stringed folk chordophones (the source of sound is a vibrating string), there is the subgroup of plucked instruments, which encompasses the gusli, the kobza, the bandura, the torban. According to the Hornbostel-Sachs system, their classification number is 321.311 (312) - 5, where 321 stands for the lute; 311, for a bowl-shaped resonator (man-made or natural); 312, for a box resonator (composed of several planks); 5, for playing with the fingers. At present, it is impossible to establish whether the modern bandura belongs to the lute family, as it is a fretless instrument; though in the system, there is a specific index for complex chordophones - 32; it is used to indicate the instruments which have the characteristics of the lute (the neck), the harp (the strings are within the frame, 322.22 the pedal harp), the zither (the strings are stretched across the body).

The analysis of the above classifications shows that they are based on the principle of affinity/difference between particular types (kinds, varieties, groups, subgroups) of instruments, i.e. they set the parameters of the form, the construction, the tuning of an instrument, the method of playing, the repertoire, the manner of performance, and others, which means that there is a direct connection between the construction of the instrument and its structure, the manner of performance, the repertoire.

The evolution of the bandura related to the development of European chordophones, to such factors as searching the ways to amplify the sound of an instrument (changing the size of the body and the length of the strings), extending its scale (in accordance with the manner of sound production), using hollow resonators.

According to Z. Shtokalko, '... the Ukrainian kobza-bandura remained naturally connected with the specificity of traditional music and its form, especially later, in the time of the Ukrainian Baroque, also called the Cossack Baroque; it became an indispensable instrument for accompanying the Cossack epos. In its evolutionary development, this instrument, unlike lute-type ones, gradually deviated from universalism adjusting to the specific diatonism, scale tones, harmonic traditions that did not fit into the limiting frames of "universal" European major/minor and tempered scale' [13, p. 7]. It was the time of the formation of the main kobzar modes, whose pitch range determined the specific form of the instrument. 
The dynamics of the constructive improvements of the instrument up to the early 20th century were evidence of the bandura's evolution - it had adopted the achievements of European instrumentalism; at the same time, it could convey the specificity of Ukrainian folk melodies. In the process of its evolution, the position of the instrument changed from horizontal to vertical, the number of strings was increased (additional treble strings were stretched over the soundboard), the symmetrical position of the neck in relation to the body was changed to the off-centre one, the tuning of the instrument was changed, performers started using both hands - the bass strings were plucked with the fingers of the left hand and the treble strings were strummed with the fingers of the right hand [16]; the technique of stopping the strings was gradually abandoned, the array of playing techniques was diversified (the influence of the techniques of playing the gusli, the guitar, the lute, and other kindred musical instruments). There was also an undeniable fact of the influence of 'fashionable' tendencies on the life of traditional instruments (as it was the case with the torban) - less widespread instruments, whose melodic scale did not correspond to the national musical tradition, gradually came out of use. By the beginning of the 20th century, the Chernihiv, Poltava, Kharkiv regional traditions of playing the bandura had been firmly established; there were differences in the form and tuning, the manner of holding the instrument, the techniques of playing, the repertoire.

In the early $20^{\text {th }}$ century, most of of the instruments had the same form and tuning; it was evidence of the advantage of the pear-shaped, asymmetrical bandura over the round, symmetrical one. On the new instrument, the number or the treble strings was increased; it retained the general diatonic tuning; the treble strings were tuned in the type of the Natural or Dorian Minor Scales.

The provision of instruments was an important factor in the history of the bandura. The instrument was very popular, so many bandura makers, who used both Ukrainian and European musical achievements, proposed their own models. Throughout the $20^{\text {th }}$ century, the instrument was being steadily improved, which made it possible to broaden its repertoire, to stimulate the teaching process, and to change the style of performance.

One of the proponents of the new instrument was Hnat Khotkevych, an experienced design engineer and musicologist, a kobza expert (the spheres of the models of the instrument, its repertoire and techniques), a talented composer, a virtuoso bandurist. He was the first to raise the problem of the uniformity of the bandura. H. Khotkevych was the organizer of the first bandurist ensemble, its members representing different schools of performance. In 1902, the ensemble performed at the 12th Archaeological Congress in Kharkiv. The need for the uniformity of the instrument's characteristics (the form and tuning, the manner of holding and playing the bandura) became evident.

Stanyslav Lyudkevych pointed out the potential of the instrument unlocked by H. Khotkevych, 'Even now, in the hands of Mr. Khotkevych, the bandura is an incomparable instrument when it comes to accompanying folk songs; if only its limited diatonic scale were extended, if it were made suitable for some modulations without retuning .., it would be quite a cultured instrument' [6, p. 184].

Here S. Lyudkevych implied the variability of tuning proposed by $\mathrm{H}$. Khotkevych (different toneto-semitone ratio in adjacent octaves). The innovation made it possible to emphasize the European major key used in different styles of music and to preserve the variability of the kobzar modes.

S. Lyudkevych paid special attention to the place of the instrument in the system of chordophones, the relationship between the bass and the melody strings, the specificity of its tuning and performance. He stated that 'By the criterion of its construction, the bandura belongs to the group of chordophones, the subgroup of so-called harp-type instruments (Harfeninstrumente), i.e. fretless ones, whose strings can produce only one sound each, vs. the subgroup of so-called zither-type instruments (Lauteninstrumente), whose strings, while pressed against the frets, are raised by a semitone' [6, p. 183]. S. Lyudkevych drew attention to the specific 'kobzar' key of the bandura, the combination of the Dorian Minor Scale and the European harmonic minor, which determined the tuning and the repertoire of the instrument in the early $20^{\text {th }}$ century.

\footnotetext{
${ }^{*}$ S. Lyudkevych believed that zither-type and lute-type instruments belonged to the same subgroup.
} 
S. Lyudkevych was in favour of the chromatization of the bandura; he believed it to be not only a likely change, but a necessary improvement. He claimed that 'since the 16th century, the bandura, whatever its origin, has been exclusively the property of the Ukrainian people; it kind of merged with the historical life of the nation; and now its construction, some characteristic features (the two types of strings in particular) indicate that the bandura is a typical, traditional Ukrainian folk instrument, to which no analogous can be found in any other culture. In my opinion, the bandura has to be dear and near to every Ukrainian' [6, p. 184].

Unlike M. Lysenko, who supported O. Famintsyn in that it was a heterochthonous instrument, S. Lyudkevych and then $\mathrm{H}$. Khotkevych stated that the bandura was a plucked stringed instrument indigenous to Ukraine [10].

The construction of the modern bandura and the mode of sound production are quite peculiar - the bandura combines the characteristics of lute-like, harp-like, and zither-like instruments. The difference between them lies, first of all, in the parameters of the external shape of the instruments.

Harp-like instruments are played in vertical position; they have no neck and the strings are attached to the frame; it allows two-side access to the plane of the strings that are plucked with the fingers of both hands. 'The modern double-action pedal harp combines the basic structure and sound of ancient harps with a complex mechanism in order to obtain a full chromatic pitch range' [17]. The strings are mostly synthetic and partly metal. The bandura and harp-like instruments have certain characteristics in common: the free plucking of the strings, the free use of both hands over the plane of the strings, the majority of their texture elements, the total key switching. The bandura differs from harp-like instruments in that the bass strings run from the neck to the body and the treble strings are stretched over the soundboard, the performer's hands move in the direction away from you from lower-pitched to higher-pitched sounds, and the performer plays on one side of the instrument.

Lute-like instruments are held in horizontal position. They have a deep, pear-shaped body, a circular sound hole under the strings, and the neck. The strings (gut or nylon, with metal windings on the lower-pitched strings) attached to the tuning pegs on the headstock run from the neck of the instrument to the body. Thus the performer plucks open strings or strings pressed against the frets, which requires the use of both hands. Some advanced lute-like instruments have the tonal modulation system. Both the bandura and lute-like instruments have the neck and the strings running from the neck to the body; unlike the lute, the bandura is not a fretted instrument any more owing to the increased tension of the strings.

The distinguishing feature of various zither-like instruments is the plane of the diatonic strings, which run in a fan-like fashion or parallel to the soundboard. 'The strings nearest the player run above a fretted fingerboard against which they are stopped by the left hand to provide melody notes; they are plucked by a plectrum worn on the right thumb. At the same time, the right-hand fingers pluck an accompaniment on the farther strings, which remain unstopped' [18]. Zither-like instruments, both horizontal and vertical ones, have a sound hole; the modern instruments have the system of chromatization and tonal modulation. The modern bandura, like some zither-like instruments, is held vertically; other characteristics they have in common are the related methods of playing and the musical texture; the major difference between the bandura and zither-like instruments is that the former is a fretless instrument.

Thus, the bandura is a plucked stringed instrument, which combines the characteristics of lute-like, harp-like, and zither-like instruments. The $20^{\text {th }}$ century Ukrainian and Ukrainian diaspora masters took on the tasks of improving its construction and playing technique, and introducing new genres into its repertoire. The modern history of the bandura (the $20^{\text {th }}-$ the early $21^{\text {st }}$ century) may be divided into several periods.

The innovations of first period (the 1910s-1920s) were as follows: the new, asymmetrical form of the instrument was generally accepted; the asymmetrical shape made it possible to increase the number of the treble strings; the bandura retained its general diatonic tuning with the melodic minor scale on the treble strings. H. Khotkevych continued to work on the unification of the Kharkiv bandura. The serial production of the instrument was set up in Moscow and Kyiv. 
In the 1930s (the second period), the first attempts at the chromatization of the Kyiv and the Kharkiv banduras were made. The sound range of the instrument was extended. H. Khotkevych, L. Haydamaka, H. Sniehirov, H. Paliivets worked on the improvement of the Kharkiv bandura, their priority being the design of the orchestral instruments (piccolo, prima, bass). Some important state programmes were launched: the Kyiv bandura workshop at the Kyiv State Bandurist Capella was set up, the Chernihiv musical instrument factory was open. O. Korniievskyi, P. Chepurnyi, V. Tuzychenko devised the tonal modulation mechanisms for the Kyiv bandura, which made it possible to chromatize the scale of the instrument.

The third period (the 1940s) brought many significant changes. It was the period of organologic experiments in the Ukrainian diaspora: there appeared the many-stringed bandura designed by V. Yemetz, the bandura family (prima, alto, bass, and contrabass) made by I. Skliar for the Kyiv State Bandurist Capella, the 'Poltavka' bandura designed by the Honcharenko brothers - Alexander and Peter.

During the fourth period (the 1950s), attempts were made to revive the Kharkiv bandura in Ukraine (P. Ivanov). The diaspora makers V. Yemetz, the Honcharenko brothers, S. Lastovych-Chulivskyi sought to improve the Kharkiv bandura. The musical instrument factories started to manufacture the banduras designed by O. Korniievskyi and I. Skliar.

The fifth period (the 1960s-1970s) saw the production of the experimental samples of the KyivKharkiv bandura designed by I. Skliar, the family of chromatic orchestral banduras designed by I. Skliar and V. Tuzychenko (prima, bass, contrabass), a new type of the Kyiv bandura: the Lvivianka designed by V. Herasymenko. The Chernihiv musical instrument factory started mass production and began to export the Kyiv bandura.

Between the 1980s and the 2010s (the sixth period), new instruments were created: the Kharkiv model of the Lvivianka with the system of individual tonal modulation mechanisms designed by V. Herasymenko, the Kyiv-Kharkiv bandura designed by R. Hrynkiv, W. Vetzal's (Canada) and K. Bloom's (USA) new Kharkiv banduras with the system of individual key-change mechanisms; the old instruments were reconstructed from M. Lysenko's descriptions: O. Veresai's kobza, H. Tkachenko's traditional folk bandura, F. Vidort's torban reconsrtructed by M. Budnyk, a performer in the kobzar tradition. The bandura makers experimented with the materials like plastic and fiberglass [1, p. 220-222].

The changes in the construction of the kobza-bandura were determined by the internal and the external factors: the need for developing the technical potential of the instrument, which would improve its performance, and the influence of the advanced European art. The transition from the sphere of solo performance to that of the ensemble/orchestral performance and the academization of the instrument brought about the changes in its form, tuning, production technology. The improvement of both the Kyiv and the Kharkiv banduras concerned first of all the chromatization of the instruments and the extension of their pitch range. Ukrainian designers and performers I. Skliar, V. Tuzychenko O. Korniievskyi, V. Herasymenko, and others worked on the chromatization of the Kyiv bandura: the number of strings was increased, another plane of strings was added (additional series of strings between the main ones); the total key switching system was devised, which made it possible to raise the pitch of a particular string by a semitone over the entire range.

H. Khotkevych and L. Haydamaka were the first to chromatize the Kharkiv bandura; the specificity of the instrument - two hands simultaneously playing on the treble strings - was taken into account. Their work was continued by the diaspora bandurists and designers V. Yemetz, H. Dovzhenko, the Honcharenko brothers, S. Lastovych-Chulivskyi, A. Chornyi, and others.

Modern banduras (the Lvivianka, the Chernihiv bandura) are wide-range multitimbral instruments; their other advantage is the system of key modulations; these innovations have considerably raised the technical level of performance. The system of individual switches (one for each bass and treble string) has made it possible to chromatize the Khakiv bandura. This method of key switching involves slowing down the rate of performance when sudden modulations are needed; on 
the other hand, a performer can use the entire complex of the techniques typical of the Kharkiv school (playing with both hands on the bass and treble strings) and the specific kobzar modes.

The main criteria for the analysis of the instrument are its timbre and technical characteristics: the pitch range; the specificity of sound production, which determines the playing techniques and the picking style, the musical texture, the audio volume; the dominant genres of the repertoire. The pitch range of the bandura has been changing throughout the centuries. At the early stage of its evolution, the bandura was a fretted instrument, the strings were pressed against the neck, thus the pitch range was extended. Later, fretted playing was substituted by plucking strings of fixed height. Additional strings (of the upper and lower registers) and the chromatization (partial or total) of the instrument resulted in further extension of its pitch range. The modern bandura allows of two types of chromatization: total (changing the sound of a string over the entire pitch range of the instrument) and individual (changing the sound of each string).

Plucked stringed instruments are played with the fingers or nails (natural or artificial ones) or with a plectrum. The peculiarity of the bandura is not only the technique of plucking the strings with the flesh of the fingers or the fingernails or both; it is also the autonomous movements of the hands on the strings, i.e. parallel sound production. It makes the bandura different from kindred musical instruments such as the kantele, the gusli, and others; playing them, a performer has to use both hands simultaneously. The improvement of the instruments has made it possible to use them in the sphere of academic music, while the traditional sphere of their use has been narrowed. For instance, unlike the bandura, some other plucked chordophones - the harp, the kantele, the kanun, the kusle - are no longer used as vocal/instrumental instruments, i.e. they do not accompany singing any more. The bandura has been partly affected by these processes. The modern Kyiv bandura is not fit for performing folk epics with their specific modes, though it has retained its role as an instrument to accompany singing in other genres (ballads, art songs); additionally, collective performance has become popular.

The bandura as a stringed plucked instrument has a long history of development and improvement. Its evolution was influenced by external processes in Eurasian musical instrumentalism; it was also determined by the needs and the specificity of the folk performing traditions. The symbiosis of lute-like, harp-like, and zither-like instruments has resulted in the emergence of new plucked stringed instruments of various forms and names in different parts of the world, which accounts for common and distinctive national characteristics of the plucked chordophones.

\section{REFERENCES}

[1] Дутчак В. Бандурне мистецтво українського зарубіжжя: монографія. Фоліант, Івано-Франківськ, 2013. [Dutchak V. Bandurne mystetstvo ukrainskoho zarubizhzhia: monohrafiia. Foliant, Ivano-Frankivsk, 2013.]

[2] Зінків І. Бандура як історичний феномен: монограбія. ІМФЕ ім. М. Рильського, Київ, 2013. [Zinkiv I. Bandura yak istorychnyi fenomen: monohrafiia. IMFE im. M. Rylskoho, Kyiv, 2013.]

[3] Имханицкий М. История исполнительства на русских народных инструментах. РАМ имени Гнесиных, М., 2002.

[Ymkhanytskyi M. Ystoryia yspolnytelstva na russkykh narodnykh ynstrumentakh. RAM ymeny Hnesynykh, M., 2002.]

[4] Ластович С. Аисти про бандуру: найновіші технічні відомості, вказівки і поради про конструкціюо $i$ будову бандури (упор. Дяковський М.). Нью-Йорк, 1956.

[Lastovych S. Lysty pro banduru: nainovishi tekhnichni vidomosti, vkazivky i porady pro konstruktsiiu i budovu bandury (upor. Diakovskyi M.). Niu-York, 1956.]

[5] Левицький Р. Еволюція бандури. Бандура, 7-8 (1984), 26-30.

[Levytskyi R. Evoliutsiia bandury. Bandura, 7-8 (1984), 26-30.] 
[6] Дюдкевич С. Дослідження, статmі, рецензії, виступи (упоряд. Штундер 3.), Т. 1; Т. 2. Дивосвіт, Пьвів, 2000.

[Liudkevych S. Doslidzhennia, statti, retsenzii, vystupy (uporiad. Shtunder Z.), T. 1; T. 2. Dyvosvit, Lviv, 2000.]

[7] Мациевский И. Народный музыкальный инструмент и методология его исследования. В: Актуальные проблеми современной фольклористики. Музыка, Ленинград, 1980.

[Matsyevskyi Y. Narodnyi muzykalnyi ynstrument y metodolohyia eho yssledovanyia. In: Aktualnye problemy sovremennoi folklorystyky. Muzyka, Lenynhrad, 1980.]

[8] Мацієвський I. Пролегомени дослідження етнічної музики українського зарубіжжя. В: Ігри й співголосся. Контонація: Музикологічні розвідки. Астон, Тернопіль, 2002, 132-137.

[Matsiievskyi I. Prolehomeny doslidzhennia etnichnoi muzyky ukrainskoho zarubizhzhia. In: Ihry y spivholossia. Kontonatsiia: Muzykolohichni rozvidky. Aston, Ternopil, 2002, 132-137.]

[9] Мішалов В. Думки відносно конструкції та удосконалення бандури. В: Хоткевич Г. Бандура та ї конструкція, Сер. “Музична спадщина Гната Хоткевича", вип. 5. Торонто, Харків, Фонд національно-культурних ініціатив ім. Г. Хоткевича, 2010, 261-262.

[Mishalov V. Dumky vidnosno konstruktsii ta udoskonalennia bandury. In: Khotkevych H. Bandura ta yii konstruktsiia, Ser. "Muzychna spadshchyna Hnata Khotkevycha", vyp. 5. Toronto, Kharkiv, Fond natsionalno-kulturnykh initsiatyv im. H. Khotkevycha, 2010, 261-262.]

[10] Хоткевич Г.М. Музичні інструменти українського народу. Вид. О.Савчук, Х., 2002.

[Khotkevych H.M. Muzychni instrumenty ukrainskoho narodu. Vyd. O.Savchuk, Kh., 2002.]

[11] Черкаський Л. Українські народні музичні інструменти. Техніка, К., 2003.

[Cherkaskyi L. Ukrainski narodni muzychni instrumenty. Tekhnika, K., 2003.]

[12] Шаров К.С. Музыка как инструмент национализма. Вестник Москов. ун-та., Сер. 7. Философия, 1 (2005), 59-80.

[Sharov K.S. Muzyka kak ynstrument natsyonalyzma. Vestnyk Moskov. un-ta., Ser. 7. Fylosofyia, 1 (2005), 59-80.]

[13] Штокалко 3. Кобзарський підручник (А. Горняткевича (Ред.)). Едмонтон, Вид-во Канад. ін-ту українських студій, К., 1992.

[Shtokalko Z. Kobzarskyi pidruchnyk (A. Horniatkevycha (Red.)). Edmonton, Vyd-vo Kanad. in-tu ukrainskykh studii, K., 1992.]

[14] Штокалко 3. Критичні завваги до стану сучасного кобзарства. Українські вісті, 6 лютого, 1949; Штокалко 3. Критичні завваги до стану сучасного кобзарства. Бандура, 3-4 (1981), 11-15.

[Shtokalko Z. Krytychni zavvahy do stanu suchasnoho kobzarstva. Ukrainski visti, 6 liutoho, 1949; Shtokalko Z. Krytychni zavvahy do stanu suchasnoho kobzarstva. Bandura, 3-4 (1981), 11-15.]

[15] Hornbostel E., Sachs C. Systematik der Musikinstrumente. Ein Versuch. Zeitschrift für Ethnologie, Band 46, Hefte 4-5, 1914, 553-590.

[16] Bandura: Musical Instrument.In: Encyclopedia Britannica: School and Library Subscribers. Available at: https://www.britannica.com/art/bandura.

[17] Harp: Musical Instrument. In: Encyclopedia Britannica: School and Library Subscribers. Available at: https://www.britannica.com/art/harp-musical-instrument.

[18] Zither: Musical Instrument. In: Encyclopedia Britannica: School and Library Subscribers. Available at: https://www.britannica.com/art/zither.

Address: Violetta Dutchak, Vasyl Stefanyk Precarpathian National University, 57, Shevchenko Str., IvanoFrankivsk, 76025, Ukraine.

E-mail: violetta.dutchak@ukr.net.

Received: 21.07.2017; revised: 29.09.2017. 
Дутчак Віолетта. Українська бандура як музичний інструмент групи хордофонів. Журнал Прикарпатського університету імені Василя Стефаника, 4 (2) (2017), 125-133.

У статті запропоновано аналіз відмінностей бандури як музичного інструмента групи щипкових хордофонів. Узагальнення результатів дослідження грунтуються на висновках провідних музикознавців, виконавців, етноорганологів С. Аюдкевича, Е. Горнбостеля, К. Закса, Г. Хоткевича, 3. Штокалка та ін. Представлено морфологію бандури, основні періоди iї еволюції крізь призму інструментознавчих критеріїв. Визначено стабільні й мобільні елементи ії структури й строю. Виокремлені технічні характеристики бандури на різних етапах удосконалення іï конструкції майстрами України й української діаспори. Акцентовано увагу на спільних та відмінних показниках бандури й споріднених інструментів.

Ключові слова: бандура, хордофон, струнний щипковий інструментарій, морфологія інструмента, конструкція. 